\title{
Somatotrophin Measurement
}

National Cancer Institute

\section{Source}

National Cancer Institute. Somatotrophin Measurement. NCI Thesaurus. Code C80360.

The determination of the amount of somatotrophin present in a sample. 